\title{
O PROCESSO DE INCORPORAÇ̃̃o de TRATAdOS INTERNACIONAIS: NOVAS PERSPECTIVAS JURISPRUDENCIAIS
}

The procedures regarding incorporation of International Treaties: new perspectives from Brasilian Supreme Court

Ricardo Gueiros Bernardes Dias

Doutor em Direito pela UGF/University of California (San Francisco), Mestre em Direito pela UGF/UERJ. Graduado em Direito pela Universidade de Brasília (UnB). Professor de Direito Constitucional e Direito/Processo Penal da Universidade Federal do Espírito Santo (UFES). Visiting Researcher da Univeristy of California. E-mail: ricardoeroberta.gueiros@gmail.com.

\section{João Guilherme Gualberto Torres}

Graduando em Direito pela Universidade Federal do Espírito Santo (UFES). Monitor da disciplina de Direito Constitucional II na mesma Universidade. Participante do Programa Institucional de Iniciação Científica da UFES (PIIC). E-mail: joaoggtorres@hotmail.com.

\section{Resumo}

O presente artigo, com análise crítica da jurisprudência da Suprema Corte, pretende enfrentar a recepção normativa interna dos tratados internacionais versados em direitos humanos, temática esta que não deve se encontrar alheia à preocupação acadêmico-doutrinária. Em verdade, muitos ainda os desafios na compreensão de que, sendo o escalonamento uma escolha político-legislativa, não cabe ao intérprete a livre construção de ideias, através de mecanismos desvinculados das normas constitucionais. A opção constituinte deve, em atenção à construção de um Estado Democrático de Direito, ser respeitada.

Palavras-chave: Tratados. Hierarquia. EC 45/2004. Pacto de São José da Costa Rica. Direitos humanos. 


\begin{abstract}
This article, with a critical analysis of the case law of the Supreme Court, intends to address the incorporation of international treaties versed in human rights; this issue should not be analyzed without the academic and doctrinal concern. In fact, the remain challenges, since the hierarchy (between the Statutes) is a political option, the interpreter cannot be free in his ideas, without focusing the constitutional rules. The legislative option should, in consideration of creating a democratic state of law, be respected.
\end{abstract}

Keywords: Treaties. Hierarchy. Constitutional Amendment n 45/2004. Pact of SAN José. Human RIGHTS.

SuMÁRIo: Introdução. 1. A hierarquia das normas jurídicas. 1.1. A relação existente entre direito interno e direito internacional. 2. A incorporação de Tratados Internacionais sobre Direitos Humanos: as teorias existentes. 2.1. O caminho trilhado pela jurisprudência na incorporação dos Tratados Internacionais sobre Direitos Humanos. 2.2. A perspectiva no âmbito do direito comparado. 3 . Perspectivas futuras, ou de como devemos aplicar as teses ora expostas. 3.1.A proposta regimental do Congresso Nacional: as complementações legislativas necessárias. Conclusão. Referências.

\title{
INTRODUÇ̃̃o
}

Ficamos, por vezes, a imaginar quais seriam as conseqüências de um ordenamento jurídico sem um escalonamento hierárquico. Em verdade, esse questionamento traz, em outras palavras, uma indagação mais profunda, o que não é objeto precípuo da presente investigação, ou seja, qual a (real e eventual) necessidade de haver um sistema hierárquico de normas. Ora, são elas entes amórficos. Estaríamos escalonando esses entes para fins de regulação de quem os criou? Mas, independentemente desse aspecto, é dessa problemática (a hierarquização) que nosso conflito (problemática) vem à tona.

O presente trabalho tem por escopo um exame mais acurado, e atual, da incorporação do direito internacional no ordenamento jurídico pátrio, máxime após a Emenda Constitucional n. 45/04, a qual acresceu, entre outros, ao artigo $5^{\circ}$ da Magna Carta, o parágrafo $3^{\circ}$, que versa sobre o procedimento de votação de tratados internacionais de direitos humanos.

A importância, embora vastos já sejam os posicionamentos do Supremo 
Tribunal Federal na matéria, não se cinge à hierarquia assumida pelos tratados de direitos humanos, senão que se busca avançar e perquirir acerca dos próximos passos a serem dados; isto é, de que forma os tratados antes da Emenda Constitucional 45, ou mesmo antes da Constituição de 88, devem ser analisados. Em linha de conta, traz-se a lume a proposta de alteração do regimento interno do Congresso Nacional, modificadora do quórum de votação de tratados internacionais, em alinhamento, já tardio, com a EC em epígrafe.

De lá para cá, é-nos exigido adequação, diante do novo paradigma trazido pela mencionada emenda, de todo o ordenamento jurídico. Assim, não mais se admite possa haver restrições indevidas a direitos e garantias fundamentais, uma vez pactuado, a nível internacional, a defesa interna dessas conquistas.

$\mathrm{O}$ estudo mais detido da estrutura escalonar do ordenamento jurídico brasileiro é fundamental ao desenvolvimento de questões que possam, por ventura, vir a ser enfrentadas, porquanto, a cada dia, maior a dependência mútua entre os Estados, numa necessidade de cooperação, para a satisfação das mais diversas carências.

O tema em especial, demonstra a preocupação, sempre válida, da colocação pátria em meio ao quadro internacional que se amolda em clara preocupação com a defesa dos direitos humanos e os mais diversos e coletivos valores.

Nesta quadra da historia, ainda há resistência a que a incorporação escolhida pelo legislador tenha sido consentânea com as exigências políticas da época, mas que não podem, ainda assim, ser suplantadas por teorias que visam a alçar voos mais altos.

\section{A hierarquia daS nORMaS JURídicas}

É antiga a visão de que a estrutura escalonada das normas jurídicas serve como parâmetro para estudo do ordenamento jurídico. A importância reside na facilidade de perceber-se de que forma é possível que uma norma retire de outra seu fundamento de validade, possibilitando não só o fortalecimento, em último grau, de uma Constituição rígida, como também realçando aquilo que nela vem pregado por vontade do legislador.

De acordo com tal estudo, toda norma retira seu fundamento de validade de outra norma, superior, por excelência, formando, assim, uma estrutura suprainfraordenada na qual é possível surgir um mosaico piramidal, em que normas inferiores estejam de acordo com normas superiores, ao menos no primeiro momento dessa visualização.

Em consequência, haverá um momento em que, não sendo possível um regresso ao infinito, uma norma última há de ser pressuposta como fundamento de validade para todo o ordenamento jurídico. A essa norma, Hans Kelsen atribuiu o nome de "norma fundamental hipotética" (Grundnorm), a qual não retira seu fundamento de validade de outra norma, senão que se apresenta como um 
fato produtor de normas, a atribuição de poder a uma autoridade legisladora ou - o que significa o mesmo - uma regra que determina como devem ser criadas as normas gerais e individuais do ordenamento fundado sobre essa norma fundamental ${ }^{343}$.

Esse último parâmetro de validade permite que qualquer outra norma, de escalão inferior, possa, ou não, manter-se no ordenamento jurídico observado. Certo é que, por presunção de validade, toda e qualquer norma é passível de adentrar na estrutura escalonada, ali permanecendo até que outra norma, revogadora, a anule porque não condizente com o parâmetro de validade preestabelecido.

Interessante questão traz Lenio Streck ${ }^{344}$, como uma das dificuldades encontradas no Brasil. Isto é, a ausência de uma verdadeira teoria das fontes não consegue dimensionar os problemas havidos pela não compreensão do estamento galgado por determinada norma jurídica dentro do ordenamento pátrio; e de que forma sua hierarquia se faz possível a depender do órgão legiferante ou do procedimento já previamente estabelecido. Mais abaixo se apontará a mudança trazida no bojo da Emenda Constitucional n. 45/04, ao prever procedimento específico (semelhante ao de votação de emenda constitucional) para tratados versados em direitos humanos.

Em verdade, pensamos tratar-se de problema atinente a toda realidade jurídica. São comuns as queixas por pessoas insertas na área que juízes andam descumprindo a legislação, apondo às decisões a própria marca de personalidade e de pessoalidade. Em livre convencimento e em libertinagem interpretativa, tem-se observado prolação de decisões desvencilhadas do suporte fático textual, escamoteando-se o texto legal.

Assim, também, ocorre com a ânsia acadêmico-doutrinária em propagar, tão logo ratificado o tratado internacional, os direitos e garantias acolhidos em seu bojo, sem, por vezes, mínima preocupação na forma com que se deve dar a incorporação desses acordos entre Estados.

Não se franqueia que a Constituição seja ela mesma “"complementada' por qualquer aplicador, à revelia do processo legislativo regulamentar (portanto, à revelia do princípio democrático)"345. O contrário seria pactuar com uma suposta autorização para ativismos, que acabam por redundar em decisionismos.

Indagar, por isto, o critério de pertença de uma norma é, antes de tudo, conferir-lhe, de acordo com os mandos constitucionais postos por autoridade competente, de que modo passa a ser válido no sistema jurídico o preceito normativo legislado, ou se se preferir, incorporado.

Não é, porém, de fácil resolução a questão atinente ao colocado em debate.

${ }^{343}$ KELSEN, Hans. Teoria pura do direito. 8 ed. São Paulo: Martins Fontes, 2009. p. 219.

${ }^{344}$ Cf. STRECK, Lenio Luiz. Verdade e consenso. 4 ed. São Paulo: Saraiva, 2011.

${ }^{345}$ STRECK, Lenio Luiz. O que é isto - decido conforme minha consciência? - 3 ed. Porto Alegre: Livraria do Advogado Editora, 2012. p. 47. 
A adoção de diretrizes internacionais e a colocação do Brasil na órbita externa impõe considerar os anseios referentes à abertura, cada vez maior à defesa de minorias, dos direitos humanos e de classes e gêneros ditos hipossuficientes. Não é outra senão a velha formação de um "Estado Constitucional Cooperativo", nas palavras de Peter Häberle.

Contudo, ainda que possa parecer antipático aos olhos de tantos, sobrepujar a vontade constitucional de disciplinar ou não em espaço interno o relevo dado a esses pactos é igualmente repudiar o texto constitucional e desvencilhar-se dos critérios adotados pelo constituinte, representante democrático das escolhas de um povo.

Assim, com Friederich Müller ${ }^{346}$, pode-se dizer que a legitimidade do poder constituinte do povo só é possível se houver a incorporação das pretensões deste ao texto (Vertextung) da Constituição, tendo por interlocutor o povo enquanto instância de atribuição, sendo que o procedimento democrático de pôr em vigor a Constituição dirige-se ao povo ativo. Sem, obviamente, descurar do cerne constitucional (democrático, por excelência) observado pelo povo-destinatário dos direitos.

\subsection{A RELAÇÃO EXISTENTE ENTRE DIREITO INTERNO E DIREITO INTERNACIONAL}

A análise da relação havida entre direito interno e direito internacional, trilhando o exposto no tópico anterior, não se assenta no conteúdo sobre o qual versa o tratado internacional, ou da ordem internacional, como um todo. Pelo contrário, funda-se, justamente, naquilo que pode ser considerado pressuposto de validade para a existência do direito internacional, se da perspectiva de que o direito internacional é ou não parte integrante do direito interno, para as teorias monistas, ou se é possível a convivência de duas ordens simultâneas, e, por conseguinte, de dois fundamentos de validade (teoria dualista ou pluralista).

Para aqueles adeptos da teoria dualista, existiriam duas ordens jurídicas coexistentes, internacional e nacional, que poderiam vir a ser diferenciadas na fonte (vontade do Estado), nos sujeitos (indivíduos ou Estados) e no conteúdo (subordinação ou coordenação) $)^{347}$.

De acordo com a teoria dualista, enquanto no direito interno, a vontade emana do próprio Estado, no direito internacional exige-se a vontade conjunta dos Estados. Decerto, é algo a diferenciar entre as ordens normativas sobre as quais se debruça, haja vista, na estrutura interna, ser possível enxergar-se o eixo vertical que fundamenta a estrutura jurídica interna. De outro modo, no plano internacional, a inexistência de um órgão único supranacional e sancionador, possibilita a que só seja possível a mantença do direito internacional através dos acordos bi ou plurilaterais, pelos quais se obriga o próprio Estado.

\footnotetext{
${ }^{346}$ MÜLLER, Friederich. Quem é o povo? São Paulo: Max Limonad, 2003. p. 108.

347 JEVEAUX, Geovany Cardoso. Direito constitucional: teoria da constituição. Rio de Janeiro: Forense, 2008. p. 296.
} 
Quanto ao conteúdo, a preocupação da ordem interna em normatizar a conduta dos indivíduos, dos sujeitos nacionais, sendo que no direito internacional a atenção se volta aos interesses supranacionais.

Em posição mais moderada, propugna-se pela obrigatoriedade das leis no âmbito interno, e pela incidência da regra do pacta sunt servanda, em âmbito internacional.

Nenhuma das duas teorias dualistas (ou pluralistas), todavia, está imune a críticas, em especial, quanto à lógica de sua construção. Com supedâneo em Kelsen, não se pode aceitar que dois complexos de normas formem um sistema normativo unitário, delimitados nos respectivos domínios de validade, um em face do outro. Para tanto, seria, ainda, necessário, um terceiro e superior ordenamento, que os delimitasse e os coordenasse. Eis que "a determinação do domínio de validade é a determinação de um elemento de conteúdo do ordenamento jurídico inferior pelo superior" 348 .

A diferença entre as duas existentes construções monistas, todavia, reside em que, a seguir o pensamento kelseniano, aquela que toma o direito interno como fundamento de validade para a ordem internacional, pressupõe-se que a primeira constituição histórica, cujo ordenamento forma o ponto de partida da construção, é um fato gerador de direito. De outro lado, a teoria monista que sustenta o primado da ordem internacional sobre a interna, não toma qualquer ordem interna como ponto de partida, senão que se sustenta na própria ordem internacional o fundamento de validade, pressuposta por virtude da qual o costume é um fato gerador de direito ${ }^{349}$.

O ponto fulcral é, pois, observar tratar-se de política a prevalência, adotada a teoria monista, do direito interno ou do direito internacional. Se o próprio Estado é quem se obriga no plano internacional, dele parte a maior ou menor vontade de reduzir sua soberania e submeter-se às regras pactuadas em nível horizontal com demais Estados. De fato, não há qualquer elemento que o obrigue a se limitar mais ou menos em plano internacional, senão a sua vontade política.

Assim, também, ocorre com o processo de integração regional e os direitos nacionais (p. ex., Mercosul), exigindo-se, para tanto, o desenvolvimento de "um mecanismo original de coexistência entre a ordem jurídica" ${ }^{350}$ e os anseios integrativos.

Salienta-se que "não existe uma teoria jurídica que conceitue as relações entre o direito dos processos de integração e os ordenamentos jurídicos nacionais" 351 .

\footnotetext{
${ }^{348}$ KELSEN, Hans. Teoria pura do direito. 8 ed. São Paulo: Editora WMF Martins Fontes, 2009. p. 369.

${ }^{349}$ KELSEN, Hans. Teoria pura do direito. 8 ed. São Paulo: Editora WMF Martins Fontes, 2009. p. 378.

${ }^{350}$ KEGEL, Patrícia Luiza; AMAL, Mohamed. Instituições, Direito e Soberania: a efetividade jurídica nos processos de integração regional nos exemplos da União Europeia e do Mercosul. Revista Brasileira de Política, vol. 52, n. 1, Brasília, jan./jun., 2009.

${ }^{351}$ Idem. Ibidem.
} 
A criação de uma ordem comunitária é, mais uma vez, fruto da política exercida pelos Estados adeptos da vontade de aproximação, quer seja por elementos culturais, sociais, políticos ou econômicos.

Nesses tempos, é de se observar, em que a busca pelo pacifismo se faz contundente e a necessidade de ajuda externa mútua é cada vez mais evidente, os laços criados a nível supraestatal suplantam as diferenças culturais, étnicas, religiosas e acabam exigindo do Estado um posicionamento de inserção na ótica globalizada ${ }^{352}$. O que Kelsen chamaria de Weltanschauung em matéria de submissão ou não aos tratados internacionais e em que grau no direito interno.

Com o advento da Emenda Constitucional n. 45/2004, optou o constituinte brasileiro, adotando a teoria monista, por fazer prevalecer a ordem interna, porquanto esta estabeleceu, de antemão, o procedimento necessário para a incorporação dos tratados internacionais sobre direitos humanos a nível constitucional, do que se pode deduzir a sistemática quanto aos demais acordos internacionais.

A EC n. 45/04 surge como marco delimitador do mecanismo de incorporação porque, pela primeira vez, dita o procedimento necessário para que os direitos humanos, pactuados na esfera externa, alcancem status de normas constitucionais, pacificando a celeuma, ao menos num primeiro momento (e a nível legislativo), existente na doutrina e na jurisprudência.

Acreditando em que a crescente intensificação das relações internacionais pudesse, um dia, levar à supremacia da comunidade internacional, logo após a promulgação da Constituição de 1988, aduzia Celso Ribeiro Bastos que, vindo a consumar-se, em sua inteireza a noção de submissão dos Estados às normas internacionais, heteronomamente impostas, "estará superada a própria noção de Estado". De modo que, "a organização política da humanidade terá assumido uma natureza e feição profundamente diversa daquelas dominantes em nossos dias" 353, 354.

\footnotetext{
352 Em crítica aguda à resistência à incorporação dos Tratados internacionais sobre Direitos humanos, embora pouco destoante dos lindes do afirmado neste ensaio, conferir LEITE, Carlos Henrique Bezerra. Direitos humanos. 2 ed. Rio de Janeiro: Lumen Juris, 2011. pp. 24-26, passim.

353 BASTOS, Celso Ribeiro. Comentários à constituição do brasil. São Paulo: Saraiva, 1988. p. 262.

354 Pérez Luño, citado por André Ramos Tavares, sustenta que "no processo de constitucionalização dos direitos fundamentais o positivismo teve um papel importante ao colocar a exigência de uma concreção jurídica dos ideais jusnaturalistas, para dotálos de autêntica significação jurídico-positiva. Contudo, os acontecimentos políticos se encarregaram de evidenciar, em certas ocasiões, de forma trágica, a necessidade de situar a fundamentação do sistema da liberdades públicas em uma esfera que ultrapassa o arbítrio da jurisdição interna de cada Estado". In TAVARES, André Ramos. Curso de direito constitucional. 10 ed. São Paulo: Saraiva, 2012. p. 553.
} 


\section{A incorporação de Tratados Internacionais sobre Direitos Humanos: AS TEORIAS EXISTENTES}

Com a ratificação da Convenção Americana sobre Direitos Humanos (Pacto de São José da Costa Rica - Decreto 678/92) e com a adesão brasileira ao Pacto Internacional de Direitos Civis e Políticos (Decreto 592/92), interessante discussão frequentou o meio acadêmico e doutrinário, indo parar na jurisprudência da Suprema Corte. Tratava-se, pois, de indicar a hierarquia assumida pelos tratados internacionais sobre direitos humanos no ordenamento jurídico brasileiro, tendo surgido várias vertentes, entre as quais ${ }^{355}$ : a) supraconstitucionalidade ${ }^{356}$; b) hierarquia constitucional ${ }^{357}$; c) supralegalidade ${ }^{358}$; d) status de lei ordinária ${ }^{359}$.

Duas colocações são importantes. Em primeiro lugar, deve-se observar o grau hierárquico ocupado por tratados que versem sobre direitos humanos, pois, do contrário, assumirão eles mesmos status da legislação ordinária.

Curioso notar, a esse respeito, o art. 98 do Código Tributário Nacional (CTN), segundo o qual "os tratados e convenções internacionais revogam ou modificam a legislação tributária interna, e serão observados pela que lhes sobrevenha" (grifou-se). O preceito normativo em tela não somente aduz a respeito da revogação por incorporação superveniente de tratados internacionais em matéria tributária, o que se assemelharia à adoção do mesmo grau hierárquico, havendo derrogação por critério cronológico, como, ainda, passado este momento, condicionaria as demais legislações futuras, limitando o legislador na elaboração normativa. É dizer, se incorporado, assume um caráter supralegal, condicionando a atividade legiferante.

Há, portanto, desde a década de 40, previsão, infraconstitucional, diga-se

\footnotetext{
355 MENDES, Gilmar Ferreira. Curso de direito constitucional. 7. ed. São Paulo: Saraiva, 2012. pp. 656-675, passim.

${ }^{356}$ Representativo da defesa desta teoria, o eminente professor Celso Albuquerque Mello.

${ }^{357}$ No Brasil, Antônio Cançado Trindade e Flávia Piovesan perfilharam o entendimento de hierarquia constitucional a ser atribuída aos tratados que versem sobre Direitos humanos.

358 Entendimento que restou esposado no paradigmático julgamento do RE 466.343/SP, de relatoria do ex-Ministro Cezar Peluso, julgado em 3 de dezembro de 2008.

${ }^{359}$ Esta a posição adotada pelo Supremo Tribunal Federal quando ainda precoce a discussão da matéria, anteriores, os julgados, à EC n. 45, seguindo jurisprudência firmada na Corte. Cf. RE 80.004/SE, Rel. Min. Xavier de Albuquerque, julgado em $1^{\circ}$ de junho de 1977; ADI 1.080/DF, Rel. Min. Celso de Mello, julgada em 4 de setembro de 1997. Desta última, é possível extrair o seguinte trecho da ementa: "Os tratados ou convenções internacionais, uma vez regularmente incorporados ao Direito interno, situam-se, no sistema jurídico brasileiro, nos mesmos planos de validade, de eficácia e de autoridade em que se posicionam as leis ordinárias, havendo, em consequência, entre estas e os atos de Direito internacional público, mera relação de paridade normativa. Precedentes." E ainda se asseverou que a resolução de conflito antinômico somente seria possível através dos critérios de cronologia (lex poster derogat lex anterior) e de especialidade.
} 
de passagem, a respeito da incorporação de tratados que fugissem ao plano ordinário legislativo. Perceba-se, no entanto, que tão somente abrange a matéria tributária, o que não se cogitava até a promulgação da vigente Carta Magna e, em especial, após o advento da EC n. 45/04, quanto a tratados e convenções sobre direitos humanos.

Em segundo lugar, mister consignar a diferença substancial provocada pela inserção do $\S 3^{\circ}$ no artigo $5^{\circ}$ da Magna Carta. A previsão de procedimento semelhante ao exigido para emendas constitucionais não pode ser olvidada pelos estudiosos do direito. Parece claro que, a seguir o quórum previsto, alcançará o tratado sobre direitos humanos o mesmo grau hierárquico das demais normas constitucionais, o que inviabiliza entendimento acerca da teoria de supraconstitucionalidade ${ }^{360}$.

Segundo alguns doutrinadores, contudo, a tão só presença do $\S 2^{\circ}$, no art. $5^{\circ}$, permitindo a extensão do rol de Direitos Fundamentais e o art. $4^{\circ}$, inciso II, todos da Constituição Federal, já seriam permissivos claros de que tais acordos internacionais devessem assumir hierarquia constitucional, quiçá, supraconstitucional.

Voltando às teorias até então apresentadas pela doutrina ${ }^{361}$, a primeira delas incorpora os tratados internacionais sobre direitos humanos com status supraconstitucional, conferindo-lhes aplicabilidade imediata. Nas palavras de Bidart Campos, citado por Gilmar Mendes, "si lo que queremos es optimizar los derechos humanos, y si conciliarlo con tal propósito interpretamos que las vertientes del constitucionalismo moderno y del social han enrolado [...] en líneas del derecho interno inspiradas en un ideal análogo, que ahora se ve acompañado internacionalmente, nada tenemos que objetar (de lege ferenda) a la ubicación prioritaria del derecho internacional de los derechos humanos respecto de la Constitución" ${ }^{362}$.

Ocorre, todavia, que algumas implicações traz a adoção da referida tese. A uma, que a rigidez constitucional, desenvolvida pelo princípio da supremacia forma e material da Constituição, impediria a adequação da tese diante do quadro apresentado pelo ordenamento jurídico brasileiro. A duas, que, a prevalecer, impediria o controle de constitucionalidade dos atos internacionalmente pactuados, o que levaria ao questionamento: em havendo descumprimento do iter procedimental de incorporação dos tratados, qual solução seria adotada? Ainda, no plano material, a adequação aos direitos e garantias fundamentais já presentes no seio constitucional.

A tese de atribuição de hierarquia constitucional enxerga no $\S 2^{\circ}$ do art.

\footnotetext{
${ }^{360}$ A este propósito, interessante conferir a discussão traçada entre os Ministros do Supremo Tribunal Federal quando do julgamento do HC 87.585, de relatoria do Min. Marco Aurélio, julgado em 03.12.2008.

${ }^{361}$ Apenas para situar, conferir, entre outros, TAVARES, André Ramos. Curso de direito constitucional. 10 ed. São Paulo: Saraiva, 2012. pp.544-572; BULOS, Uadi Lammêgo. Curso de direito constitucional. 6 ed. São Paulo: Saraiva, 2011. pp. 698-712.

362 MENDES, Gilmar Ferreira. Curso de direito constitucional. 7. ed. São Paulo: Saraiva, 2012. p. 658.
} 
$5^{0363}$ da Magna Carta uma cláusula aberta de recepção de direitos outros subscritos pelo Brasil, no plano internacional, conferindo-se, ademais, aplicabilidade imediata, desde a ratificação, dispensando-se a intermediação legislativa, em leitura do $\S 1^{\circ}$ do mesmo art. $5^{0364}$.

Em caso de conflito, adotar-se-ia o princípio do in dubio pro homini ou fazendo prevalecer o princípio da dignidade humana, com o consectário da norma mais favorável à pessoa humana. Cançado Trindade asseverou que "a normativa dos tratados de Direitos humanos em que o Brasil é parte tem efetivamente nivel constitucional e entendimento contrário requer demonstração "365.

Tal doutrina esvaziou-se com o advento da EC n. 45/04, a qual, conforme já se disse, trouxe procedimento próprio de incorporação de tratados sobre direitos humanos, a nível constitucional ${ }^{366}$. A exigência de aprovação através de quórum especial no Congresso Nacional mitiga a adoção da vertente esposada pelo autor.

A vigência do mesmo parágrafo terceiro reflete, para alguns, que não pode, todavia, entender-se possível o plano meramente ordinário dos tratados incorporados. Isso porque, ao prever quórum especial, ter-se-ia ressaltado o caráter especial dos tratados sobre direitos humanos em relação aos demais tratados, os quais assumem, incontestavelmente hierarquia ordinária.

Destarte, a terceira vertente assenta-se na posição intermediária de ditos tratados, é dizer, acima do nível ordinário, da legislação comum, mas abaixo do nível constitucional, somente alcançado se aprovado, no Congresso Nacional, de acordo com o procedimento prescrito.

Por fim, a quarta e última vertente, já superada, como se verá abaixo, pela jurisprudência e pela doutrina, atribuía aos tratados incorporados o nível semelhante ao da legislação ordinária.

Uma preocupação merece ser externada e, inclusive, foi aventada em várias decisões da Suprema Corte. A caracterização dos tratados internacionais, para fins de abrangência ou não da temática dos direitos humanos poderá, num futuro próximo, gerar sérias dúvidas aos estudiosos do Direito. Isto porque nem sempre os acordos internacionais são claramente extensores do rol dos direitos humanos, abordando, por vezes, indiretamente a questão, ou, ainda, apenas fazendo referência.

${ }^{363} \mathrm{CRFB}$, art. $5^{\circ}, \S 2^{\circ}$. Os direitos e garantias expressos nesta Constituição não excluem outros decorrentes do regime e dos princípios por ela adotados, ou dos tratados internacionais em que a República Federativa do Brasil seja parte.

${ }^{364} \mathrm{CRFB}$, art. $5^{\circ}, \S 1^{\circ}$. As normas definidoras dos direitos e garantias fundamentais têm aplicação imediata.

365 MENDES, Gilmar Ferreira. Curso de direito constitucional. 7. ed. São Paulo: Saraiva, 2012. p. 661.

${ }^{366} \mathrm{CRFB}$, art. $5^{\circ}, \S 3^{\circ}$. Os tratados e convenções internacionais sobre direitos humanos que forem aprovados, em cada Casa do Congresso Nacional, em dois turnos, por três quintos dos votos dos respectivos membros, serão equivalentes às emendas constitucionais. 
Saber se versa ou não sobre direitos humanos o tratado a ser incorporado no ordenamento pátrio poderá causar transtornos tanto no momento da votação parlamentar, quando se buscará aferir o procedimento adequado de votação, quanto no controle de constitucionalidade.

Não se pode, ademais, perder de vista que defensores há que encontrarão em todo e qualquer tratado internacional algum ponto a fim de reivindicar o caráter humanitário trazido em seu bojo, para fins de benefícios que poderão ser alcançados de acordo com o status hierárquico assumido. A deturpação na apreensão dos fins do Direito das gentes não pode descambar para o alvedrio de motivações ideológicooportunistas, senão que deverá haver profícua proteção de aspectos humanistas existentes a nível internacional, plano este almejado pelo Estado brasileiro, alinhando-se às demais potências com os mesmos e bem definidos escopos.

\subsection{O CAMINHO TRILHADO PELA JURISPRUdÊNCIA Na INCORPORAÇão dOS TRATA- dos InTERnacionais sobre Direitos Humanos}

Sob a ótica da inserção do Brasil perante o cenário internacional, uma frase sempre nos chamou a atenção. Era (e é) um costumeiro raciocínio de Camen Tiburcio ${ }^{367}$ : Dizia ela (e ainda diz) que nossa nação, durante boa parte de sua história, praticou uma espécie de isolacionismo no tocante sua participação no cenário internacional. Não faz, assim, tanto tempo que o Brasil passou a ratificar um número mais substancial de tratados internacionais. Isso, portanto, é uma (apenas uma!) das razões que levaram a jurisprudência a tardar em mostrar suas primeiras balizas quanto à incorporação e posição hierárquica dos tratados internacionais. Além disso, não se olvida que os diferentes tratamentos - concedidos pelos mais diversos Estados - também corroboram para uma falta de sistematização. Com isso (e também por outros motivos), a problemática da antinomia no âmbito internacional encontra percalços além daqueles vistos em um ordenamento jurídico interno, como esmiuçado acima.

De uma forma ou de outra, nosso leading case sobre a matéria remonta ao período anterior à Constituição de 1988, como fizemos menção em nota anterior. Estávamos no ano de 1977, quando o Supremo Tribunal Federal apreciou o Recurso Extraordinário 80.004. Tratava-se de analisar a Convenção de Genebra, especificamente, a Lei Uniforme sobre Letras de Câmbio e Notas Promissórias. Discutia-se o conflito entre o Decreto-Lei n. 427/69 e o referido Tratado Internacional (promulgado pelo Decreto n. 57.663/66).

Tratava-se, portanto, de averiguar a questão do critério hierárquico, uma vez que, quanto ao critério temporal, não haveria maiores dúvidas e que, no tocante

367 TIBURCIO, Carmen. Conflito entre fontes: os casos da prisão do depositário infiel e devedor fiduciante e as leis uniformes de Genebra: comentários à súmula vinculante 25. Revista de Direito Bancário e do Mercado de Capitais. São Paulo, v. 50, p. 245, out. 2010. 
à especificidade, percebeu-se que ambas as normas possuíam natureza semelhantes. É só após a promulgação da Constituição de 1988 é que a discussão volta ao palco da jurisprudência. E isso se dá porque, pela primeira vez, uma norma constitucional pátria resolve tratar, mesmo que timidamente, da matéria. Como já salientado, o $\S 2^{\circ}$ do art. 5o preceituava originariamente (e ainda preceitua) que "os direitos e garantias expressos nesta Constituição não excluem outros decorrentes do regime e dos principios por ela adotados, ou dos tratados internacionais em que a República Federativa do Brasil seja parte."

A redação, com efeito, poderia gerar interpretações diversas. Mas as primeiras interpretações doutrinárias pareciam seguir um caminho mais lógico. O que estaria a Constituição a dizer quando preceituava que não haveria exclusão de outras garantias, por exemplo, criadas por tratados internacionais? Seria apenas uma previsão constitucional a permitir que tratados - que versassem sobre direitos e garantias fundamentais - pudessem (no sentido permissivo) ser incorporados ao ordenamento jurídico interno? Ou seria um dispositivo constitucional que teve por condão posicionar os tratados internacionais em situação hierárquica similar à Constituição (ou, no mínimo, superior às normas infraconstitucionais)? Sim, fazemos essas perguntas por um motivo lógico. Não haveria muitas outras opções hermenêuticas (sustentáveis).

E o maior percalço seria a obviedade da resposta à primeira pergunta: não. Não acreditamos que $\S 2^{\circ}$ do art. 5o teria um escopo óbvio de permitir (ou seja, apenas permissivo) que tratados internacionais trouxessem ao ordenamento jurídico novos direitos e garantias fundamentais. Concluir de forma contrária nos levaria a uma intepretação absurda: que, sem essa previsão constitucional, os tratados só poderiam regular matérias que não disciplinassem direitos e garantias fundamentais. Ora, uma norma que não dispensa um processo legislativo mais rigoroso que a formação de uma lei ordinária estaria - estranhamente - limitada a situações de somenos importância. E mais: seria ilógico, agora sob a ótica material, imaginar que as normas internacionais só poderiam - ao menos no âmbito pátrio - disciplinar assuntos de menor importância. Haveria, em tese, uma outra conclusão absurda. Se se precisasse dizer que os tratados podem criar novos direitos e garantias fundamentais, concluiríamos dizer que a Constituição também precisaria deixar expresso que as normas infraconstitucionais também teriam essa prerrogativa (o que, obviamente, é desnecessário).

Dissemos "percalço" porque isso faria restar apenas uma interpretação, precisamente aquela que nos faria responder positivamente à segunda pergunta. Não que isso seja de todo mal. Pelo contrário. O problema é que, no afã de uma recém -editada Constituição, impulsionada por um movimento democrático, parecia haver uma certa resistência do Supremo Tribunal Federal em aceitar uma hierarquia constitucional de uma norma (seja internacional, ou não), que não fosse proveniente de um poder constituinte. Estava claro que a resistência não estava no caráter transfronteiriço da norma. Esse caráter veio a acalentar as discussões. Aliás, não fosse isso seria desnecessário maior esforço hermenêutico. 
E essa resistência ficou claramente demonstrada logo após os primeiros casos analisados pelo Supremo Tribunal Federal. Interessantes as palavras de Sepúlveda Pertence ao relatar o primeiro processo $^{368}$ em que teve a oportunidade de examinar a questão de forma mais exauriente. É que o tema foi encarado pelo Tribunal duas vezes, pelo menos: a primeira, no HC 72.131, 23.11.95, Moreira Alves - relativa à compatibilidade da prisão civil do depositário infiel ou equiparado com o art. $5^{\circ}$, LXVII, CF, e com o Pacto de São José - e na ADinMC 1.480, 25.9.96, Celso de Mello - acerca da constitucionalidade da Convenção 158 da Organização Internacional do Trabalho. Ambos os acórdãos lamentavelmente ainda aguardam publicação. Mas, no primeiro, fiquei vencido, dada a inteligência restritiva que empresto à permissão constitucional da prisão do depositário infiel, independentemente da superveniência da Convenção Americana; e, no segundo, a nitidez das posições ficou um tanto comprometida com a circunstância de a Convenção possuir caráter programático - como a mim e a outros juízes pareceu - ou, pelo menos, admitir interpretação conforme, que exclua qualquer pretensão de eficácia plena e imediata (Inf. STF, n. 82) como entendeu a maioria (ver ementa do voto condutor do Ministro Celso de Mello, transcrito no Inf. STF 135).

Assim, quanto ao período pós-Constituição de 88, parece ter sido dado, nesse caso, um tratamento mais definidor. Ao dissertar, longamente, sobre as diversas posições doutrinárias (como também fizemos acima), o ministro relator colocase a favor da tese segunda à qual não haveria razão para modificar o entendimento já pacificado anteriormente à promulgação da $\mathrm{CF}$ de 88 , qual seja, o tratado internacional possuiria hierarquia similar à da lei ordinária.

O fundamento-base poderia ser resumido em um raciocínio: "que, ao menos no Brasil, o tratado internacional não pode ultrapassar os limites impostos pela Constituição da República. E a razão para tanto, está na natureza estável do texto constitucional '. Em outras palavras, o exercício hermenêutico, a nosso ver, derivou de uma intenção predisposta em colocar a Constituição acima de qualquer outra norma. Utilizou-se, inclusive, o argumento de que o art. 59 da CF já deixava claro o caráter rígido da Carta.

Disso, podemos tirar duas conclusões: 1)essa interpretação nos leva a uma inocuidade do $\S 2^{\circ}$ do art. 5o (ao menos quanto ao assunto que estamos a tratar), na esteira do que relatamos acima; 2)para mudar o cenário, seria necessário lidar com a rigidez da $\mathrm{CF}$.

E essa barreira (no que toca ao problema da rigidez), precisaria ser ultrapassada mediante uma emenda constitucional. Essa mudança vem com a, já mencionada, "reforma do judiciário", mediante a qual é inserido o $\S 3^{\circ}$ do art. 5o. Interessante. Poder-se-ia optar pela mudança da redação do $\S 2^{\circ}$, já que, pela nossa conclusão, o dispositivo seria inócuo. Optou-se, entretanto, em criar subsequente parágrafo, como se o dispositivo constitucional original não precisasse de um esclarecimento e, sim,

${ }^{368}$ RHC 79785. Relator Min. Sepúlveda Pertence. Julgamento: 29.03.2000. 
de um aditamento (o que não nos parece fosse o caso).

A nova redação, contudo, não foi bastante, em termos jurisprudenciais, para esclarecer o tema (ao menos para o STF). Como já transcrevemos, diz o $\S 3^{\circ}$ do art. 5o: "Os tratados e convenções internacionais sobre direitos humanos que forem aprovados, em cada Casa do Congresso Nacional, em dois turnos, por três quintos dos votos dos respectivos membros, serão equivalentes às emendas constitucionais.”.

E, aqui, a história se repete. A história da resistência a que nos referimos nos parágrafos anteriores. Mas, agora, a situação (hermenêutica) nos parece mais séria. É que se o problema era a rigidez (e a rigidez é derivada exatamente do grau de dificuldade - em termos comparativos - da aprovação da emenda constitucional), ele seria sanado com a promulgação da EC 45/04.

A resistência, entretanto, dessa vez, não parece ter-se dado tanto em razão do caráter da rigidez, mesmo porque foi precisamente esse aspecto que a EC 45/04 veio superar. A resistência, como veremos abaixo, parece ter tido um motivo mais técnico-processual, qual seja, o fato de não se estar analisando, in casu, um tratado aprovado sob a força do $\S 3^{\circ}$ do art. $5^{\circ}$ da CF. Isto é, o máximo que o STF poderia ter realizado (e, infelizmente, o fez muito timidamente) seria um esclarecimento obiter dictum, quanto a esse novel parágrafo constitucional.

Ao analisar o Recurso Extraordinário 466.343, cuja relatoria foi incumbida ao Min. Cezar Peluso, houve uma divergência significativa. O Min. Gilmar Ferreira Mendes salientou

[...] que os tratados internacionais de direitos humanos subscritos pelo Brasil possuem status normativo supralegal, o que torna inaplicável a legislação infraconstitucional com eles conflitantes, seja ela anterior ou posterior ao ato de ratificação [...].

Por sua vez, o Min. Celso de Mello, divergindo nesse ponto, afirmou que

no que respeita à atribuição de status supralegal aos tratados internacionais de direitos humanos subscritos pelo Brasil, afirmou terem estes hierarquia constitucional. No ponto, destacou a existência de três distintas situações relativas a esses tratados: 1) os tratados celebrados pelo Brasil (ou aos quais ele aderiu), e regularmente incorporados à ordem interna, em momento anterior ao da promulgação da $\mathrm{CF} / 88$, revestir-se-iam de índole constitucional, haja vista que formalmente recebidos nessa condição pelo $\S 2^{\circ}$ do art. $5^{\circ}$ da CF; 2) os que vierem a ser celebrados por nosso País (ou aos quais ele venha a aderir) em data posterior à da promulgação da EC $45 / 2004$, para terem natureza constitucional, deverão observar o iter procedimental do $\S 3^{\circ}$ do art. $5^{\circ}$ da $\mathrm{CF} ; 3$ ) aqueles celebrados pelo Brasil (ou aos 
quais nosso País aderiu) entre a promulgação da $\mathrm{CF} / 88$ e a superveniência da EC 45/2004, assumiriam caráter materialmente constitucional, porque essa hierarquia jurídica teria sido transmitida por efeito de sua inclusão no bloco de constitucionalidade ${ }^{369}$.

Ao refutar os argumentos o Min. Gilmar Mendes asseverou:

A despeito da belíssima sustentacão dos argumentos e também dos respaldos doutrinários, entendo que, no caso, corremos o risco de produzirmos uma atomização de normas constitucionais. Identificados os tratados de direitos humanos como de hierarquia constitucional, passaremos a ter essas normas como parâmetro de controle, gerando, portanto, um quadro de insegurança jurídica. ${ }^{370}$

Esses argumentos acabaram, entretanto, por serem obiter dictum, pois não modificaram o decisum. Ou seja, a divergência não foi determinante para eventual alteração no julgado, qual seja, a vedação da prisão civil nos casos do depositário infiel.

Tanto isso é verdade (o caráter obiter dictum do ponto), que o Min. Cesar Peluso, ao aditar seu voto (exatamente em razão do pronunciamento dos demais ministro), disse:

Neste ponto, abstenho-me de examinar a questão da taxinomia, entre nós, dos tratados internacionais aprovados, promulgados e incorporados ao ordenamento jurídico, porque me parece que, qualquer que seja a postura teórica em relação à autoridade e ao valor nomológico desses tratados, o resultado jurídico e prático será o mesmo para os casos concretos que estamos a julgar. [..] Assim, a mim me parece - pelo menos neste julgamento - irrelevante saber qual o valor, a autoridade ou a posição taxinômica que os tratados internacionais ocupam perante o ordenamento jurídico brasileiro. $^{371}$

E mais: o ministro relator chega a antecipar eventual futuro voto a respeito da precisa posição hierárquica dos tratados internacionais: "Em relação aos casos futuros e a eventual caso posto perante o novo Código Civil, já antecipo, para excluir a terceira alternativa, minha posição de que vou reconhecer caráter supralegal ou caráter constitucional ao Tratado. "372 A palavras finais deixam clara a dúvida que

\footnotetext{
${ }^{369}$ Informativo STF n. 498.

370 Íntegra do voto do Recurso Extraordinário 466.343.

${ }^{371}$ Idem.

${ }^{372}$ Idem.
} 
ainda paira sobre a temática.

Mas como vimos, a discussão não enfrentou, de forma minimamente exauriente, a questão do $\S 3^{\circ}$ do art. $5^{\circ}$ da CF. Arriscaríamos a dizer que, nesse ponto, o Supremo Tribuna Federal se posicionará de forma mais homogênea e, quiçá, como ratio decidendi. Como parece adiantar (uma vez mais em caráter obiter dictum) o Min. Gilmar Mendes no discutido RE 466.343:

Enfim, desde a adesão do Brasil no ano de 1992, ao Pacto dos Direitos Civis e Políticos (art. 11) e à Convenção Americana sobre Direitos Humanos - Pacto de San José de Costa Rica (art. $\left.7^{\circ}, 7\right)$, não há base legal para a aplicação da parte final do art. $5^{\circ}$, LXVII, da Constituição, ou seja, para a prisão civil do depositário infiel".

[...]

De qualquer forma, o legislador constitucional não fica impedido de submeter o Pacto Internacional dos Direitos Civis e Políticos e a Convenção Americana sobre Direitos Humanos - Pacto de San José de Costa Rica, além de outros tratados de direitos humanos, ao procedimento especial de aprovação previsto no art. $5^{\circ}, \S 3^{\circ}$, da Constituição, tal como definido pela EC n. 45/04, conferindo-lhes status de emenda constitucional.

Em outras palavras, a tese da supralegalidade (mas, ao mesmo tempo, concedendo caráter infraconstitucional aos tratados) só se coadunaria quanto aos tratados não aprovados segundos os ditames $\S 3^{\circ}$ do art. $5^{\circ}$ da CF (ou não "convertidos" mediante o mesmo processo).

Isso implica concluir que o Supremo Tribunal Federal, embora não enfrentando a novidade inserida na EC 45/04, modificou seu entendimento anterior quanto à aplicação do (então) inócuo $\S 2^{\circ}$ do art. $5^{\circ}$ da $\mathrm{CF}$, que agora possui, ao menos, a eficácia de alçar os tratados internacionais a um nível supralegal.

\subsection{A PERSPECTIVA NO ÂMBITO DO DIREITO COMPARADO}

Quando se trata de comparar diversos sistemas jurídicos, o primeiro (e, talvez, também o último) entrave envolve a própria diferença cultural, notadamente em razão de não haver institutos similares entre os ordenamentos, sem prejuízo do obstáculo dos rituais e da linguagem diferenciadas.

O que é muito bem descrito por GEERTZ $Z^{373}$ :

Assim como a navegação, a jardinagem e a poesia, o direito e a etnografia também são artesanatos locais: funcionam à luz do saber local. Um caso

373 GEERTZ, Clifford. O saber local: novos ensaios em antropologia interpretativa. 4. ed. Petrópolis: Vozes, 2001. p. 249. 
individual, seja ele o de Palsgraff ou o da Ponte sobre o Rio Charles, proporciona ao direito não só as bases que dão origem a toda uma série de reflexões, mas também o próprio objeto que lhe dá orientação; [...]. Sejam quais forem as outras características que a antropologia e a jurisprudência possam ter em comum - como por exemplo uma linguagem erudita meio incompreensível e uma certa aura de fantasia, ambos se entregam à tarefa artesanal de descobrir princípios gerais em fatos paroquiais. Repetindo, uma vez mais, o provérbio africano: "a sabedoria vem de um monte de formigas".

No que toca à atual temática, torna-se árdua a tarefa de, até mesmo, descrever como outros países tratam da matéria. É que, de uma forma geral, o âmago de toda a problemática reside em um ponto em comum: o escalonamento das normas, de que tanto tratamos na presente pesquisa. Por sua vez, nem todos os outros Estados mantêm esse arcabouço eclético e complexo de escalonamento de normas. E, mesmo que tivessem, a forma de lidar com o escalonamento é realizado de forma diversa.

Tomando, apenas a título exemplificativo, os países adotantes do sistema common law, temos que, mais do que a hierarquia em si, o caráter cogente, ou não, da norma se vê como o cerne da questão.

Por essa razão, imprescindível conhecer a noção das - tão rotineiras - expressões soft law e hard law $w^{374}$.Atribuir uma definição para soft law tem sido uma tarefa complexa entre os doutrinadores, porque a própria expressão soft law enseja um paradoxo. Tal paradoxo advém do simples fato de que direito representa em grandes linhas algo obrigatório, capaz de impor sanção, preciso, hard e assim oposto a algo não obrigatório, genérico, flexível, soft. Logo, pergunta-se se o adjetivo soft utilizado para qualificar o direito suscita de início que este novo instrumento difere-se do direito em sua acepção usual (hard law) constituindo-se assim num direito diferenciado ou se o uso do termo soft indica tratar-se de algo que não seja direito. Se admitido o soft law como direito, este deve ser identificado como diferente, pois não será obrigatório, será um direito com normas relativizadas. Se considerado como um não direito, constata-se que as regulamentaç̃oes se ampliam no âmbito não jurídico. Nesse contexto, algumas escolhas são indispensáveis. Nossa primeira escolha está em considerar que o direito vai além do obrigatório, logo os instrumentos de soft law são para nós um direito não obrigatório.

Essa não-obrigatoriedade (caráter não-cogente) - o aparente paradoxo apresentado pelos autores no início do parágrafo - deriva da premissa da relação jurídica entre os Estados, ou seja, a coordenação, que perdeu o lugar para a subordinação, que nada mais é do que uma característica das normas cogentes.

${ }^{374}$ BERTOLDI, Márcia Rodrigues Bertoldi; OLIVEIRA, Liziane Paixão Silva. A importância do soft law na evolução do direito internacional. Revista do Instituto do Direito Brasileiro, Ano 1 (2012), n. 10. p. 6268-6269. 
Em outras palavras, fica claro que a maioria dos trabalhos científicos nessa seara parece trilhar caminho diverso do nosso. Em vez de discutir-se (como ponto nodal) a incorporação do tratado (e mais: com qual hierarquia seria essa entrada), essas noções têm a clara preocupação em afirmar um outro caráter do direito, ou seja, o fato de as normas terem um sem-número de texturas. O grau de obrigatoriedade da norma, portanto, é o âmago da problemática, razão pela qual ganha relevo a expressão soft law.

Haveria, com efeito, um aparente paradoxo. É que se, por um lado, os tratados indubitavelmente "nascem" para serem obedecidos, sob o manto da obrigatoriedade, por outro, ganham a característica de soft law. O problema é que, mais do que normas jurídicas, esses tratados mais parecem uma forma de declaração política, em que a mensagem normativa possui um caráter muito mais de coordenação diplomática (reforçando a ideia do início deste tópico, qual seja, a fraqueza da subordinação). ${ }^{375}$

Em síntese, Joseph Gold parece nos trazer uma palavra que bem denota a "força normativa" dessa espécie de regra: o respeito ${ }^{376}$.

Expliquemos. Embora o termo "soft" possa denotar, logo de início, uma fraqueza da espécie normativa ${ }^{377}$, Jacob Gersen ${ }^{378}$ afirmar que as normas soft law incluem regras tais como a Declaração de Direitos Humanos. Mas que, apesar de faltar-lhe um status de formalidade legal, essas normas podem, com efeito, gerar efeitos manifestos, em razão da necessidade de cooperação entre as nações, razão pela qual fazemos alusão ao "respeito" a que se refere Gold.

375 É a solução que nos aponta BOYLE, Alan E. in Some Reflections on the Relationship of Treaties and Soft Law. The International and Comparative Law Quarterly, Vol. 48, No. 4 (Oct., 1999). p. 902-903. "There are several reasons why soft law instruments may represent an attractive alternative to law-making by treaty. First, it may be easier to reach agreement when the form is non-binding. Use of soft law instruments enables states to agree to more detailed and precise provisions because their legal commitment, and the consequences of any non-compliance, are more limited. Secondly, it may be easier for some states to adhere to non-binding instruments because they can avoid the domestic treaty ratification process, and perhaps escape democratic account-ability for the domestic treaty ratification process, and perhaps escape democratic accountability for the policy to which they have agreed."

${ }^{376}$ GOLD, Joseph. Strengthening the Soft International Law of Exchange Arrangements. The American Journal of International Law, Vol. 77, No. 3 (Jul., 1983). p. 443.

${ }^{377}$ Motivo pelo qual alguns scholars chegam a usar a expressão "Rhetorical Talismam" para tais normas. Cf. HANDL, Gunther F et al. A hard look at soft law. Proceedings of the Annual Meeting, Amercian Society of International Law, Vol. 82 (April 20-23, 1988), p. 371.

${ }^{378}$ GERSEN, Jacob E.; POSNER, Eric A. Soft Law: Lessons from Congressional Practice. Stanford Law Review, Vol. 61, No. 3 (Dec., 2008). p. 575. 


\section{Perspectivas futuras, ou de como devemos aplicar as teses ora expostas}

Diante do cenário delineado, outros desafios surpreendem o estudioso do direito, máxime quando se debruça na acomodação dos tratados internacionais na órbita interna.

Dentro do esposado neste ensaio, cumpre, ainda, relevar encaminhamentos necessários à abordagem de dois exemplos que, esperamos, em breve virá a exigir da Suprema Corte um posicionamento mais contundente.

O Pacto de San Jose de Costa Rica, no art. 23 (Direitos Políticos), 2, assegura que, in verbis: "a lei pode regular o exercício dos direitos e oportunidades a que se refere o inciso anterior ${ }^{379}$, exclusivamente por motivos de idade, nacionalidade, residência, idioma, instrução, capacidade civil ou mental, ou condenação, por juiz competente, em processo penal" (grifou-se).

Ocorre que, atualmente, a suspensão dos direitos políticos ${ }^{380}$ está prevista na Lei n. 8.249/92 (Lei de Improbidade Administrativa), no art. 12, incisos I, II e III. Senão vejamos:

Art. 12. Independentemente das sanções penais, civis e administrativas previstas na legislação específica, está o responsável pelo ato de improbidade sujeito às seguintes cominações, que podem ser aplicadas isolada ou cumulativamente, de acordo com a gravidade do fato:

I - na hipótese do art. 9. ${ }^{\circ},[\ldots]$ suspensão dos direitos políticos de 8 (oito) a 10 (dez) anos $[\ldots]$;

II - na hipótese do art. 10, [...] suspensão dos direitos políticos de 5 (cinco) a 8 (oito) anos [...];

III - na hipótese do art. 11, [...] suspensão dos direitos políticos de 3 (três) a 5 (cinco) anos $[\ldots]$.

\footnotetext{
${ }^{379}$ Decreto 678/92, art. 23, 1. Todos os cidadãos devem gozar dos seguintes direitos e oportunidades: a) de participar da direção dos assuntos públicos, diretamente ou por meio de representantes livremente eleitos; b) de votar e ser eleitos em eleições periódicas autênticas, realizadas por sufrágio universal e igual por voto secreto que garanta a livre expressão da vontade dos eleitores; e c) de ter acesso em condições gerais de igualdade, às funções públicas de seu país.

${ }^{380}$ Segundo João Barbalho, "políticos se dizem os direitos que entendem com a organização constitucional do Estado e as relações entre este e os cidadãos no que pertence à governação pública. Nesses direitos se compreende o de intervir e tomar parte no exercício da autoridade nacional. E isto mostra a importância e fundamento da exigência da posse deles como condição de elegibilidade para o cargo de Presidente da República. Por isso não podem ser eleitos os que se acharem compreendidos nas hypotheses de suspensão e perda dos direitos políticos". Apud RAMAYANA, Marcos. Direito eleitoral. 4 ed. Rio de Janeiro: Impetus, 2005. p. 126.
} 
Assim, importando os atos de improbidade em ato ilícito (art. $9^{\circ}$ ), causando prejuízo ao erário (art. 10) ou atentando contra os princípios da Administração Pública (art. 11), o agente público ${ }^{381},{ }^{382}$ teria suspensos seus direitos políticos, condição de elegibilidade, de acordo com o art. 14, $\S 3^{\circ}$, II da Magna Carta. Nas palavras de Marcos Ramayana, "o cidadão fica afastado temporariamente da capacidade eleitoral ativa e passiva (direito de votar e ser votado)"383.

A Suprema Corte, porém, já decidiu que a Ação de Improbidade Administrativa é de cunho civil, e não penal. Na Reclamação n. 2.138-6/DF restou assentado que a interpretação do art. $37, \S 4^{\circ}$ da Constituição Federal, ao ressalvar que a ação de improbidade importará em sanções, "sem prejuízo da ação penal cabível", permite aduzir, tão somente, ter a AIA natureza eminentemente civil ${ }^{384}$.

Igualmente, no julgamento da ADI n. 2.797/DF, anterior à reclamação, já se afirmava o caráter civilístico da Ação de Improbidade Administrativa, ao se declarar inconstitucional a Lei n. 10.628/02, a qual acresceu ao art. 84, do Código de Processo Penal os $\S \S 2^{\circ}$ e $3^{\circ}$.

$\mathrm{Na}$ linha de interpretação desenhada pelo próprio STF, conforme já explicado acima, por ocasião do RE 466.343/SP, apenas se pode inferir que, ocupando a posição hierárquica de supralegalidade, a Convenção Americana sobre Direitos Humanos (Pacto de São José de Costa Rica) encontra-se em grau hierárquico superior à Lei de Improbidade Administrativa.

Semelhante ao ocorrido com a prisão civil do depositário infiel $\left(\mathrm{CF}\right.$, art. $5^{\circ}$, LXVII), nada obstante a previsão da suspensão dos direitos políticos no art. $37, \S 4^{\circ}$ da Constituição, ao se reconhecer a natureza civil da Ação de Improbidade, inviável a cominação de tal sanção, uma vez que o Pacto apenas possibilita a referida suspensão através de "condenação, por juiz competente, em processo penal" (Decreto n. $678 / 92$, art. 23,2 ).

$\overline{{ }^{381} \text { Lei n. } 8.429 / 92}$, art. $2^{\circ}$ : Reputa-se agente público, para os efeitos desta Lei, todo aquele que exerce, ainda que transitoriamente ou sem remuneração, por eleição, nomeação, designação, contratação ou qualquer outra forma de investidura ou vínculo, mandato ou cargo, emprego ou função nas entidades mencionadas no artigo anterior.

${ }^{382}$ Aqui não se adentra à discussão sobre se a Lei de Improbidade se aplica ou não aos agentes políticos, embora se reconheça a existência do debate doutrinário e as inúmeras decisões do STJ e do STF contrárias ao exarado na Rcl. n. 2.138-6/DF, Rel. Min. Nelson Jobin, Rel. p/ acórdão Min. Gilmar Mendes, j. em 13.06.2007, Dje 18.04.2008.

383 Op. cit. p. 126.

${ }^{384}$ Renato Bretz Pereira relembra que "o Ministro Barbosa reitera que as sanções constitucionais para os atos de improbidade administrativa têm natureza eminentemente civil, conforme se infere do próprio texto do art. $4^{\circ}$ do artigo $37 \mathrm{da} \mathrm{CF}$, o qual se refere à incidência das sanções por improbidade, '[...] sem prejuízo da ação penal cabível [...]”". PEREIRA, Renato Bretz. O regime de responsabilização dos agentes políticos proposto por ocasião do julgamento da reclamação 2.138-6. De jure: revista jurídica do Ministério Público de Minas Gerais, Belo Horizonte, v. 12, n. 20, pp. 310-327, jan./jun., 2013. 
Não remanesce, pois, regulação jurídica para a suspensão dos direitos políticos por condenação em Ação de Improbidade Administrativa. A exemplo do decisum no RE 466.343/SP, se se seguir a coerência que se espera do Supremo Tribunal Federal, este deverá, tendo assentado o caráter supralegal do Pacto de São José, declarar haver insubsistência ("efeito paralisante"385) da legislação ordinária para fins de condenação de suspensão de direitos políticos em ações de natureza não penal.

\subsection{A proposta regimental do Congresso Nacional - as complementa- ÇÕES LEGISLATIVAS NECESSÁRIAS}

Exsurge, entretanto, o problema advindo da aprovação do $\S 3^{\circ}$ do art. $5^{\circ}$ da CF. Seria possível "converter" os tratados internacionais aprovados (ainda sob a égide da redação constitucional original) em normas com nível hierárquico segundo a nova redação? E como seria realizada essa "conversão"? 386

Visando à regulamentar a matéria, foi proposto, no âmbito da Câmara dos Deputados, o Projeto de Resolução 204/2005, que propõe a criação do artigo 203-A, $\S 10$, no Regimento Interno da Câmara dos Deputados:

$\S 10$. Tratados e convenções internacionais sobre direitos humanos ratificados pelo Brasil antes da promulgação da EC 45, de 2004, poderão ser objeto de requerimento previsto no caput deste artigo [203-A],

Art. 203-A. Recebida mensagem do Presidente da República contendo tratado ou convenção internacional sobre direitos humanos, a Mesa fará publicar no avulso da ordem do dia o prazo de dez sessões para a apresentação de requerimento subscrito por um terço de deputados solicitando sua equivalência a emenda constitucional, nos termos do $\S 3 .^{\circ}$ do art. $5 .^{\circ}$ da $\mathrm{CF}$, acrescido pela EC 45, de 2004.

Entretanto, independentemente do processo legislativo de "conversão" utilizado, a questão do tópico anterior continua. E não poderia ser diferente, tendo em vista que uma Resolução de uma das Casas do Congresso Nacional não teria o condão de esclarecer a interpretação a ser dada ao controvertido $\S 3^{\circ}$ do art. $5^{\circ}$ da CF. Mas nem parece ter sido essa a intenção da Casa Legislativa. $\mathrm{O}$ que houve

\footnotetext{
385 Abordando a temática esposada, com diferenças teóricas em relação ao presente trabalho, PRETTA, Paulo Emílio Catta. Suspensão de direito político por improbidade é inconstitucional. Revista Consultor Jurídico, 23 de janeiro de 2014. Disponível em http://www.conjur. com.br/2014-jan-23/paulo-emilio-suspensao-direito-politico-improbidade-inconstitucional. Acessado em 23.01.014.

${ }^{386}$ Note-se que, até a presente data, apenas um tratado internacional foi aprovado segundo os novos ditames: Decreto $\mathrm{n}^{\circ}$ 6.949, de 25.8.2009, que trata "sobre os Direitos das Pessoas com Deficiência e de seu Protocolo Facultativo, assinados em Nova Iorque, em 30 de março de 2007."
} 
foi um "recado" daquela Casa no sentido de conceber tal possibilidade. De qualquer forma, caberá ao Supremo Tribunal Federal, pronunciar-se a respeito da inserção desses tratados aprovados sem a observância do $\S 3^{\circ}$ do art. $5^{\circ}$ da CF.

Não vemos maior óbice; mesmo porque a proposta de Resolução nada mais faz do que equiparar a aprovação dos tratados (nos ditames do $\S 3^{\circ}$ do art. $5^{\circ}$ da $\mathrm{CF}$ ) ao processo de formação das emendas constitucionais. Importa só frisar, uma vez mais, que essa proposta não guarda qualquer relação quanto à discussão da hierarquia dessas normas, como defendem alguns doutrinadores ${ }^{387}$.

\section{Conclusão}

Para concluir, poderíamos resgatar o velho chavão: "sem pretender esgotar tema, objetivamos...". Mas não se trata disso. Nunca se "esgota" um tema. Achamos que é uma espécie de falsa humildade e/ou hipocrisia acadêmica, pois se estaria admitindo que o assunto (e pior: a conclusão desse assunto) não poderia ser revisto. $\mathrm{O}$ (pseudo)esgotamento significaria uma desnecessidade de futuras reflexões sobre o tema. E, admitir isso, nos levaria a um engessamento de uma ciência (notadamente a relativa às ciências sociais) que possui (e possuirá) uma eterna mutação, o que implica reanálises perenes. Quem afirma isso, de duas uma: ou disse menos do que gostaria de ter dito (talvez por falta de tempo); ou, realmente, crê em que um dia esgotará um assunto (o que julgamos menos provável).

Nossa breve conclusão relata mais uma preocupação do que eventuais sugestões. Desde o surgimento da Constituição de 1988, a problemática do posicionamento hierárquico no tocante aos tratados internacionais já estaria, a princípio, resolvido. A redação do $\S 2^{\circ}$ do art. $5^{\circ}$ da $\mathrm{CF}$ já seria, por si, bastante para concluir que os tratados que versassem sobre direitos e garantias fundamentais (e, aqui, não pretendemos adentrar na eterna discussão que os diferencia dos direitos humanos, no sentido conceitual) poderiam ser equiparados às emendas constitucionais.

$\mathrm{E}$, nesse sentido, reforçamos nosso entendimento de que para chegar-se a essa conclusão não precisaríamos investigar com maior profundidade as noções principiológicas extraídas da teoria constitucional, tampouco dos princípios internacionais dos direitos humanos. Bastaria um exercício hermenêutico mais simplório.

Mas o Supremo Tribunal Federal sempre foi resistente desde os primeiros julgados; talvez, como salientamos, derivado de uma cultura de momento. Uma cultura derivada de um afã que pairava nos primeiros momentos da euforia de quem

\footnotetext{
387 A propósito, interessante o estudo desenvolvido em relação ao mandado de injunção enquanto mecanismo para exercício de garantia constitucional à regulamentação dos tratados internacionais de direitos humanos fundamentais das pessoas com deficiência. ARAÚJO, Luiz Alberto David; MARTIN, Andréia Garcia; GONÇALVES, Ana Catarina Piffer. Mandado de Injunção: garantia constitucional à regulamentação dos tratados internacionais de direitos humanos fundamentais das pessoas com deficiência. Sequência, n. 62, julho, 2011, pp. 119-159.
} 
ganhou um novo guardião.

Mas não bastasse a frustrada tentativa do $\S 2^{\circ}$ do art. $5^{\circ}$ da $\mathrm{CF}$, a situação (hermenêutica), a nosso ver, se agrava quando, mesmo após o surgimento do $\S 3^{\circ}$ do mesmo dispositivo, o Supremo Tribunal Federal, quase dez anos depois, não ter ainda um posicionamento claro a respeito do tema, o que não se deu por falta de oportunidade.

O debate acerca dos aspectos do direito civil, tal como os princípios do direito cambiário e os institutos atinentes à prisão civil ganharam mais a atenção dos Ministros que, propriamente, assentar o status hierárquico de tratados internacionais sobre direitos humanos ao serem incorporados ao ordenamento pátrio.

E, segundo pensamos, os Ministros terão a oportunidade de enfrentar novamente a matéria, agora, na perspectiva da Lei de Improbidade Administrativa, esperando, desde sempre, seja a coerência mantida ou se possa, enfim, pacificar a celeuma. Mais do que isso, o respeito às teses lançadas e às normas em questão é exigência do modelo adotado.

Nesse sentido, mesmo que, de forma intelectualmente prepotente (ou mesmo ingênua) concluíssemos pelo esgotamento do tema, pouco adiantaria. É que, em nossa investigação, nossa principal conclusão é que a questão não foi sequer examinada pelo STF (ao menos como ratio decidendi).

Se, contudo, conforme acreditamos, voltar o debate a ocupar a pauta do judiciário, merecerá da Suprema Corte uma revisão crítica dos posicionamentos até então esposados, para fins de garantir maior coerência na incorporação dos tratados internacionais, bem como o respeito às balizas estipuladas constitucionalmente, máxime quanto ao $\S 3^{\circ}$ do art. $5^{\circ}$ da Magna Carta.

\section{REFERÊNCIAS}

ARAÚJO, Luiz Alberto David; MARTIN, Andréia Garcia; GONÇALVES, Ana Catarina Piffer. Mandado de Injunção: garantia constitucional à regulamentação dos tratados internacionais de direitos humanos fundamentais das pessoas com deficiência. Sequência, n. 62, julho, 2011.

BASTOS, Celso Ribeiro. Comentários à constituição do Brasil. São Paulo: Saraiva, 1988. v.1.

BERTOLDI, Márcia Rodrigues Bertoldi; OLIVEIRA, Liziane Paixão Silva. A importância do soft law na evolução do direito internacional. Revista do Instituto do Direito Brasileiro, Ano 1 (2012), n. 10. p. 6268-6269.

BOBBIO, Norberto. Teoria do ordenamento jurídico. São Paulo: EDIPRO, 2011.

BOYLE, Alan E. Some Reflections on the Relationship of Treaties and Soft Law. The International and Comparative Law Quarterly, Vol. 48, No. 4 (Oct., 1999). 
BULOS, Uadi Lammêgo. Curso de direito constitucional. 6. ed. São Paulo: Saraiva, 2011.

CHINKIN, C. M. The Challenge of Soft Law: Development and Change in International Law. The International and Comparative Law Quarterly, Vol. 38, No. 4 (Oct., 1989), pp. 850- 866.

FERRARI, Regina Maria Macedo Nery. Critérios científicos para a solução dos conflitos aparentes entre tratados internacionais e a Constituição Federal. Revista dos Tribunais, São Paulo, v. 855, p. 30, jan. 2007.

FRENCH, Duncan. Treaty Interpretation and the Incorporation of Extraneous Legal Rules. The International and Comparative Law Quarterly, Vol. 55, No. 2 (Apr., 2006), pp. 281- 314.

GEERTZ, Clifford. O saber local: novos ensaios em antropologia interpretativa. 4. ed. Petrópolis: Vozes, 2001.

GERSEN, Jacob E.; POSNER, Eric A. Soft Law: Lessons from Congressional Practice. Stanford Law Review, Vol. 61, No. 3 (Dec., 2008).

GOLD, Joseph. Strengthening the Soft International Law of Exchange Arrangements. The American Journal of International Law, Vol. 77, No. 3 (Jul., 1983).

HANDL, Gunther F et al. A hard look at soft law. Proceedings of the Annual Meeting, Amercian Society of International Law, Vol. 82 (April 20-23, 1988), pp. 371395.

HART, H. L. A. O conceito de direito. 5. ed. Lisboa: Fundação Calouste Gulbenkian, 2004.

JEVEAUX, Geovany Cardoso. Direito constitucional: teoria da constituição. Rio de Janeiro: Forense, 2008.

JUBILUT, Liliana Lyra. A aplicação do direito internacional dos direitos humanos pelo STF. Revista de Direito do Consumidor. São Paulo, v. 72, p. 78, out. 2009.

KEGEL, Patrícia Luiza; AMAL, Mohamed. Instituições, Direito e Soberania: a efetividade jurídica nos processos de integração regional nos exemplos da União Europeia e do Mercosul. Revista Brasileira de Política, vol. 52, n. 1, Brasília, jan./jun., 2009.

KELSEN, Hans. Teoria geral do direito e do estado. 3. ed. São Paulo: Martins Fontes, 1998. xico, 1982.

Teoría pura del derecho. México: Universidad Nacional Autónoma de Mé. Teoria pura do direito. 8. ed. São Paulo: Martins Fontes, 2009. 
MENDES, Gilmar Ferreira. Curso de direito constitucional. 7. ed. São Paulo: Saraiva, 2012.

LEITE, Carlos Henrique Bezerra. Direitos humanos. 2. ed. Rio de Janeiro: Lumen Juris, 2011.

McHARG, Aileen. Reforming the United Kingdom Constitution: Law, Convention, Soft Law. The Modern Law Review, Vol. 71, No. 6 (Nov., 2008).

MÜLLER, Friederich. Quem é o povo? São Paulo: Max Limonad, 2003.

PEREIRA, Renato Bretz. O regime de responsabilização dos agentes políticos proposto por ocasião do julgamento da reclamação 2.138-6. De jure: revista jurídica do Ministério Público de Minas Gerais, Belo Horizonte, v. 12, n. 20, pp. 310-327, jan./ jun., 2013.

PRETTA, Paulo Emílio Catta. Suspensão de direito político por improbidade é inconstitucional. Revista Consultor Jurídico, 23 de janeiro de 2014. Disponível em http://www.conjur.com.br/2014-jan-23/paulo-emilio-suspensao-direito-politico-improbidade-inconstitucional. Acessado em 23.01.2014.

RAMAYANA, Marcos. Direito eleitoral. 4. ed. Rio de Janeiro: Impetus, 2005.

ROMÃO, Luiz Filipe de Vasconcelos. Do Estado-nação à autonomia-nação: desafios ao conceito de soberania. Boletim Meridiano 47, Brasília, vol. 14, n. 136, mar.-abr. 2013 (pp. 3-9).

SHELTON, Dinah. Normative Hierarchy in International Law. The American Journal of International Law, Vol. 100, No. 2 (Apr., 2006).

STRECK, Lenio Luiz. Ciência politica e teoria geral do estado. 3. ed. Porto Alegre, 2003.

. O que é isto - decido conforme minha consciência? - 3 ed. Porto Alegre:

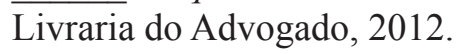

. Verdade e consenso. 4. ed. São Paulo: Saraiva, 2011.

TAVARES, André Ramos. Curso de direito constitucional. 10 ed. São Paulo: Saraiva, 2012.

TIBURCIO, Carmen. Conflito entre fontes: os casos da prisão do depositário infiel e devedor fiduciante e as leis uniformes de Genebra: comentários à súmula vincula 25. Revista de Direito Bancário e do Mercado de Capitais. São Paulo, v. 50, p. 245, out. 2010.

(Footnotes)

1 O total apresentado considera todo o período compreendido entre 1940 e março de 2013 e não apenas as frações escolhidas para esta apresentação. 